\title{
Dampak COVID-19 Terhadap Kualitas Pelayanan Perusahaan Kurir Logistik Indonesia
}

\author{
Dani Leonidas Sumarna. ST.,MT. \\ D4 Logistik Bisnis, Politeknik Pos Indonesia \\ email: danileo@poltekpos.ac.id.
}

\begin{abstract}
Abstrak
Tujuan dari penelitian ini adalah untuk mengetahui apakah ada perbedaan penilaian persepsi pelanggan jasa kurir mengenai kualitas pelayanan jasa kurir pada masa pandemi Covid-19 di Indonesia dibandingkan sebelum terjadinya pandemi covid-19. Kualitas pelayanan jasa kurir diukur dengan Logistic Service Quality (LSQ). Kuesioner dibagikan kepada 115 responden pengguna jasa kurir di Indonesia. Hasil analisis varian menunjukkan bahwa dari 13 variabel LSQ yang ditanyakan terdapat empat variabel Logistic Service Quality yang dinilai berbeda pada masa pandemi dengan sebelum pandemi, yaitu Penanganan order, Keselamatan dan keamanan saat pengiriman, kesesuaian waktu penanganan order, dan kesesuaian waktu transportasi.
\end{abstract}

Kata Kunci: Logistic Service Quality, Covid-19, Jasa Kurir Logistik, Analisis Varian.

\section{PENDAhuluaN}

Saat ini terdapat wabah penyakit yang disebabkan oleh sebuah virus. Virus tersebut telah dinamakan severe acute respiratory syndrome coronavirus 2 (SARS-Cov-2) dan penyakit yang disebabkan virus tersebut dinamakan penyakit coronavirus 2019 (COVID-19).[1] Wabah ini membuat penurunan kondisi sosial ekonomi dan resesi di banyak negara, terutama di Indonesia. Langkah-langkah yang dilakukan pemerintah untuk mencegah penyebaran wabah ini khususnya di Indonesia adalah lockdown, pembatasan industri, social distancing, karantina mandiri, dan lain-lain.[2] Beberapa penelitian membahas dampak lockdown terhadap sektor logistik. Di sektor logistik, lockdown dirasakan menghambat sistem logistik di India. [3]

Salah satu topik penelitian yang membahas Logistic service quality (LSQ) terkait dengan bagaimana mendefinisikan kualitas pelayanan dengan melakukan analisis faktor untuk mendapatkan variabel-variabel yang dianggap valid dan reliabel untuk mengukur kualitas pelayanan jasa logistik.[4]

Beberapa penelitian terkait LSQ di Indonesia membahas mengenai pengaruh LSQ terhadap variabel Customer Satisfaction dan Customer Loyalti pada industri ritel di
Indonesia yang hasilnya menyatakan bahwa LSQ memiliki pengaruh terhadap customer satisfaction dan customer loyalty.[5] Selain itu juga terdapat penelitian terkait LSQ terkait variabel Customer Satisfaction dan Customer Loyalti terkait dengan pandemi covid-19, yang menunjukkan bahwa kualitas dari staff pelayanan dan staff teknis berdampak signifikan terhadap kepuasan pelanggan pada saat pandemi.[2]

Dampak pandemi bagi aktivitas logistik di Indonesia menjadi hal yang menarik untuk diketahui, terutama dampaknya terhadap penilaian kualitas jasa pelayanan kurir yang diberikan oleh perusahaan jasa kurir logistik. Tujuan dari penelitian ini adalah untuk mengetahui apakah ada perbedaan penilaian persepsi pelanggan jasa kurir mengenai kualitas pelayanan jasa kurir pada masa pandemi Covid-19 di Indonesia dibandingkan sebelum terjadinya pandemi covid-19.

\section{METODE PENELITIAN}

Masalah yang diangkat di penelitian ini adalah untuk mengetahui apakah terdapat perbedaan penilaian persepsi pelanggan jasa kurir mengenai kualitas pelayanan jasa kurir pada masa sebelum pandemi dan pada saat terjadi pandemi. Penilaian persepsi pelanggan jasa kurir mengenai 
kualitas pelayanan pelayanan jasa kurir menggunakan variabel-variabel LSQ yang dapat dilihat pada tabel 1 .

Tabel 1 Variabel-Variabel LSQ Yang Digunakan

\begin{tabular}{|l|l|}
\hline No & Variabel \\
\hline 1 & Sikap dan Perilaku Jasa Kurir \\
\hline 2 & Respon Terhadap Kebutuhan Pelanggan \\
\hline 3 & Kompetensi Staff Jasa Kurir \\
\hline 4 & Penanganan Masukan Dari Pelanggan \\
\hline 5 & Kesesuaian Order \\
\hline 6 & Penanganan Order \\
\hline 7 & Kondisi order \\
\hline 8 & Keselamatan dan Keamanan dalam Pengiriman \\
\hline 9 & Kesesuaian Waktu Penanganan Order \\
\hline 10 & Kesesuaian Waktu Transportasi \\
\hline 11 & Kesesuaian Waktu Back Order \\
\hline 12 & Kualitas Informasi Terkait Order \\
\hline 13 & Penggunaan Teknologi informasi oleh Customer service \\
\hline
\end{tabular}

Variabel-variabel LSQ dirujuk dari penelitian Thai V V [4] mengenai LSQ. Yang menjadi responden disini adalah pengguna jasa kurir di Indonesia (yang memiliki pengalaman menggunakan jasa kurir di Indonesia pada saat sebelum terjadi pandemic dan ssudah terjadi pandemic. Responden diminta untuk memberikan penilaian terhadap variabel-variabel LSQ tersebut pada saat dua kondisi yang terjadi, yaitu sebelum terjadi pandemi dan saat terjadi pandemi.

Setelah hasil dari responden diterima, dilakukan uji normalitas untuk mengetahui distribusi data yang didapat. Jika data yang didapat berdistribusi normal, maka dilakukan uji $t$ sampel berpasangan untuk menguji perbedaan sebelum dan sesudah proses, dalam hal ini sebelum pandemi dan saat pandemi. Jika yang didapat tidak berdistribusi normal, maka dilakukan uji Wilcoxon. Hasil dari uji t sampel berpasangan atau uji Wilcoxon diharap dapat menjawab pertanyaan penelitian ini, yaitu mengetahui apakah terdapat perbedaan penilaian persepsi pelanggan jasa kurir mengenai kualitas pelayanan jasa kurir pada masa sebelum pandemi dan pada saat terjadi pandemi.

\section{HASIL DAN PEMBAHASAN}

Hasil penyebaran kuesioner yang dilakukan mendapat respon dari 115 responden.

Pengolahan data dilakukan dengan menggunakan aplikasi SPSS version 20. Uji normalitas dilakukan untuk mengetahui apakah data berdistribusi normal atau tidak. Karena analisis varian yang dilakukan berbeda terhadap data berdistribusi normal dan tidak berdistribusi normal.

\section{Statistik Deskriptif Hasil Kuesioner}

Jumlah responden terkumpul, yaitu 115 orang terdiri dari 61 laki-laki dan 54 perempuan. Kategori usia 24-45 tahun sebanyak 58 jawaban, 13-24 tahun 42 jawaban, dan 46 tahun ke atas 15 jawaban. Frekuensi penggunaan jasa kurir antara 0-3 kali per bulan sebanyak 76 jawaban, 4-10 kali per bulan 34 jawaban dan diatas 10 kali per bulan 5 jawaban.

Untuk uji varian yang diperhatikan adalah distribusi data yang didapat, yaitu apakah data berdistribusi normal atau tidak. Uji varian memberikan perlakuan yang berbeda kepada data yang berdistribusi normal dengan data yang tidak berdistribusi normal.

\section{Uji Normalitas}

Uji normalitas dilakukan untuk setiap variabel Logistic Service Quality yang ditanyakan. Data dikatakan berdistribusi normal jika nilai sig $>0,05$.

\section{a. Variabel Sikap dan Perilaku Jasa Kurir}

Hasil uji normalitas yang dilakukan dengan aplikasi SPSS 20 dapat dilihat pada tabel berikut.

Tabel 2 Hasil Uji Normalitas Variabel Sikap dan Perilaku Jasa Kurir

\begin{tabular}{|l|r|r|r|r|r|r|}
\hline \multicolumn{1}{|c|}{ Tests of Normality } \\
\hline & \multicolumn{3}{|c|}{$\begin{array}{l}\text { Kolmogorov- } \\
\text { Smirnov }\end{array}$} & \multicolumn{3}{c|}{ Shapiro-Wilk } \\
\cline { 2 - 7 } & Statistic & df & Sig. & Statistic & df & Sig. \\
\hline $\begin{array}{l}\text { Sikap dan perilaku staff } \\
\text { Jasa Kurir (sebelum } \\
\text { pandemi) }\end{array}$ & .301 & 115 & .000 & .825 & 115 & .000 \\
$\begin{array}{l}\text { Sikap dan perilaku staff } \\
\text { Jasa Kurir (saat } \\
\text { pandemi) }\end{array}$ & .297 & 115 & .000 & .828 & 115 & .000 \\
\hline
\end{tabular}

a. Lilliefors Significance Correction

Sumber : Output SPSS

Hasil uji normalitas menunjukkan bahwa nilai sig. yang didapat $<$ dari 0,05 yang menunjukkan bahwa data tidak berdistribusi normal.

b. Variabel Respon Terhadap Kebutuhan Pelanggan

Tabel 3 Hasil Uji Normalitas Variabel Respon Terhadap Kebutuhan Pelanggan

\begin{tabular}{|l|r|r|r|r|r|r|}
\hline \multicolumn{1}{|c|}{ Tests of Normality } \\
\cline { 2 - 7 } & \multicolumn{2}{|c|}{ Kolmogoro-Smirnov } & \multicolumn{3}{|c|}{ Shapiro-Wilk } \\
\cline { 2 - 7 } & Statistic & df & Sig. & Statistic & df & Sig. \\
\hline $\begin{array}{l}\text { Respon terhadap } \\
\text { kebutuhan } \\
\text { pelanggan } \\
\begin{array}{l}\text { (Sebelum } \\
\text { pandemi) }\end{array}\end{array}$ & .312 & 115 & .000 & .833 & 115 & .000 \\
\end{tabular}


Respon terhadap kebutuhan pelanggan (Saat pandemi)

a. Lilliefors Significance Correction

Sumber : Output SPSS

Hasil uji normalitas menunjukkan bahwa nilai sig. yang didapat $<$ dari 0,05 yang menunjukkan bahwa data tidak berdistribusi normal.

c. Variabel Kompetensi Staff Jasa Kurir

Tabel 4 Hasil Uji Normalitas Variabel Kompetensi Staff Jasa Kurir

Tests of Normality

\begin{tabular}{|l|r|r|r|r|r|r|}
\hline & \multicolumn{3}{|c|}{ Kolmogorov-Smirnov } & \multicolumn{3}{|c|}{ Shapiro-Wilk } \\
\cline { 2 - 7 } & Statistic & \multicolumn{1}{c|}{ df } & Sig. & Statistic & \multicolumn{1}{c|}{ df } & Sig. \\
\hline $\begin{array}{l}\text { Kompetensi Staff } \\
\text { Jasa Kurir } \\
\text { (Sebelum } \\
\text { pandemi) }\end{array}$ & .296 & 115 & .000 & .827 & 115 & .000 \\
$\begin{array}{l}\text { Kompetensi Staff } \\
\text { Jasa Kurir (Saat } \\
\text { pandemi) }\end{array}$ & .293 & 115 & .000 & .841 & 115 & .000 \\
\hline
\end{tabular}

a. Lilliefors Significance Correction

Sumber : Output SPSS

Hasil uji normalitas menunjukkan bahwa nilai sig. yang didapat $<$ dari 0,05 yang menunjukkan bahwa data tidak berdistribusi normal.

d. Variabel Penanganan Masukan Dari Pelanggan

Tabel 5 Hasil Uji Normalitas Variabel Penanganan Masukan Dari Pelanggan

Tests of Normality

\begin{tabular}{|l|r|r|r|r|r|r|}
\hline & \multicolumn{3}{|c|}{ Kolmogorov-Smirnov $^{\mathrm{a}}$} & \multicolumn{3}{|c|}{ Shapiro-Wilk } \\
\cline { 2 - 7 } & Statistic & $\mathrm{df}$ & Sig. & Statistic & df & Sig. \\
\hline $\begin{array}{l}\text { Penanganan } \\
\text { masukan dari } \\
\text { pelanggan } \\
\text { (Sebelum } \\
\text { pandemi) } \\
\begin{array}{l}\text { Penanganan } \\
\text { masukan dari } \\
\text { pelanggan (Saat } \\
\text { pandemi) }\end{array}\end{array}$ & .271 & 115 & .000 & .857 & 115 & .000 \\
\hline
\end{tabular}

a. Lilliefors Significance Correction

Sumber : Output SPSS

Hasil uji normalitas menunjukkan bahwa nilai sig. yang didapat $<$ dari 0,05 yang menunjukkan bahwa data tidak berdistribusi normal.

e. Variabel Kesesuaian Order

Tabel 6 Hasil Uji Normalitas Variabel Kesesuaian Order

Tests of Normality

\begin{tabular}{l|l} 
Kolmogorov-Smirnov $^{\mathrm{a}}$ & Shapiro-Wilk
\end{tabular}

\begin{tabular}{|l|r|r|r|r|r|r|}
\hline & Statistic & \multicolumn{1}{c|}{$\mathrm{df}$} & \multicolumn{1}{|c|}{ Sig. } & Statistic & \multicolumn{1}{c|}{ df } & Sig. \\
\hline $\begin{array}{l}\text { Kesesuaian } \\
\begin{array}{l}\text { Order (Sebelum } \\
\text { pandemi) }\end{array}\end{array}$ & .282 & 115 & .000 & .813 & 115 & .000 \\
$\begin{array}{l}\text { Kesesuaian } \\
\begin{array}{l}\text { Order (Saat } \\
\text { pandemi) }\end{array}\end{array}$ & .295 & 115 & .000 & .832 & 115 & .000 \\
\hline
\end{tabular}

a. Lilliefors Significance Correction Sumber : Output SPSS

Hasil uji normalitas menunjukkan bahwa nilai sig. yang didapat $<$ dari 0,05 yang menunjukkan bahwa data tidak berdistribusi normal.

f. Variabel Penanganan Order

Tabel 7 Hasil Uji Normalitas Variabel Penanganan Order

Tests of Normality

\begin{tabular}{|l|r|r|r|r|r|r|}
\hline & \multicolumn{3}{|c|}{ Kolmogorov-Smirnov $^{\mathrm{a}}$} & \multicolumn{3}{|c|}{ Shapiro-Wilk } \\
\cline { 2 - 7 } & Statistic & \multicolumn{1}{c|}{$\mathrm{df}$} & \multicolumn{1}{c|}{ Sig. } & Statistic & df & Sig. \\
\hline $\begin{array}{l}\text { Penanganan } \\
\text { Order (Sebelum } \\
\text { pandemi) }\end{array}$ & .290 & 115 & .000 & .809 & 115 & .000 \\
$\begin{array}{l}\text { Penanganan } \\
\begin{array}{l}\text { Order (Saat } \\
\text { pandemi) }\end{array}\end{array}$ & .316 & 115 & .000 & .831 & 115 & .000 \\
\hline
\end{tabular}

a. Lilliefors Significance Correction Sumber : Output SPSS

Hasil uji normalitas menunjukkan bahwa nilai sig. yang didapat $<$ dari 0,05 yang menunjukkan bahwa data tidak berdistribusi normal.

g. Variabel Kondisi order

Tabel 8 Hasil Uji Normalitas Variabel Kondisi Order

\begin{tabular}{|l|r|r|r|r|r|r|}
\hline \multicolumn{2}{|c|}{ Tests of Normality } \\
\hline & \multicolumn{2}{|c|}{ Kolmogorov-Smirnov ${ }^{\mathrm{a}}$} & \multicolumn{3}{|c|}{ Shapiro-Wilk } \\
\cline { 2 - 7 } & Statistic & df & \multicolumn{1}{c|}{ Sig. } & Statistic & df & Sig. \\
\hline $\begin{array}{l}\text { Kondisi Order } \\
\text { (Sebelum } \\
\text { pandemi) } \\
\begin{array}{l}\text { Kondisi Order } \\
\text { (Saat pandemi) }\end{array}\end{array}$ & .263 & 115 & .000 & .803 & 115 & .000 \\
\hline
\end{tabular}

a. Lilliefors Significance Correction Sumber : Output SPSS

Hasil uji normalitas menunjukkan bahwa nilai sig. yang didapat $<$ dari 0,05 yang menunjukkan bahwa data tidak berdistribusi normal.

h. Variabel Keselamatan dan Keamanan dalam Pengiriman

Tabel 9 Hasil Uji Normalitas Variabel Keselamatan dan Keamanan dalam Pengiriman

Tests of Normality

\begin{tabular}{|l|l} 
Kolmogorov-Smirnov $^{\mathrm{a}}$ & Shapiro-Wilk \\
\hline
\end{tabular} 


\begin{tabular}{l|r|r|r|r|r|r|}
\hline & Statistic & df & Sig. & Statistic & df & Sig. \\
\hline $\begin{array}{l}\text { Keselamatan dan } \\
\text { Keamanan } \\
\text { dalam } \\
\text { Pengiriman } \\
\text { (Sebelum } \\
\text { pandemi) } \\
\text { Keselamatan dan } \\
\begin{array}{l}\text { Keamanan } \\
\text { dalam }\end{array}\end{array}$ & .256 & 115 & .000 & .834 & 115 & .000 \\
$\begin{array}{l}\text { Pengiriman (Saat } \\
\text { pandemi) }\end{array}$ & .273 & 115 & .000 & .864 & 115 & .000 \\
$\begin{array}{l}\text { a. Lilliefors Significance Correction } \\
\text { Sumber : Output SPSS }\end{array}$ & & & & & & \\
\end{tabular}

Hasil uji normalitas menunjukkan bahwa nilai sig. yang didapat $<$ dari 0,05 yang menunjukkan bahwa data tidak berdistribusi normal.

\section{i. Variabel Kesesuaian Waktu Penanganan Order}

Tabel 10 Hasil Uji Normalitas Variabel Kesesuaian Waktu Penanganan Order

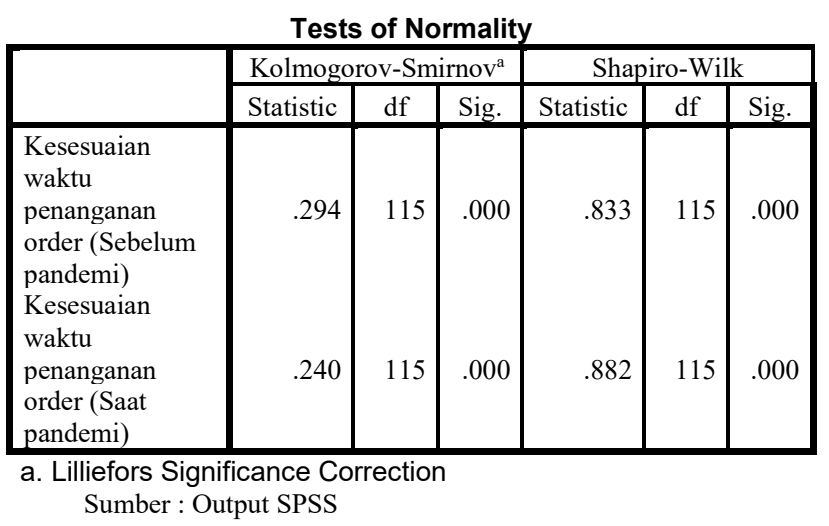

Hasil uji normalitas menunjukkan bahwa nilai sig. yang didapat $<$ dari 0,05 yang menunjukkan bahwa data tidak berdistribusi normal.

\section{j. Variabel Kesesuaian Waktu Transportasi}

Tabel 11 Hasil Uji Normalitas Variabel Kesesuaian Waktu Transportasi

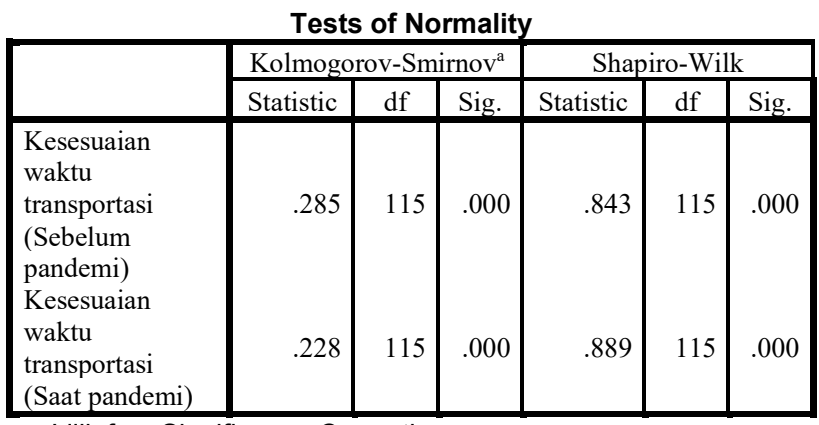

a. Lilliefors Significance Correction

Sumber : Output SPSS
Hasil uji normalitas menunjukkan bahwa nilai sig. yang didapat $<$ dari 0,05 yang menunjukkan bahwa data tidak berdistribusi normal.

\section{k. Variabel Kesesuaian Waktu Back Order}

Tabel 12 Hasil Uji Normalitas Variabel Kesesuaian Waktu Back Order

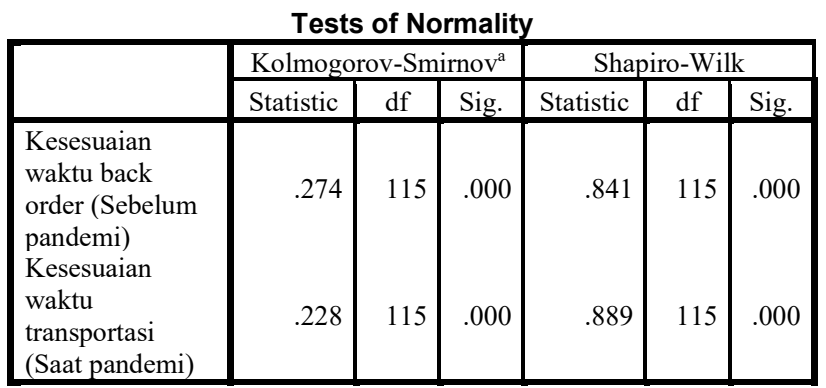

a. Lilliefors Significance Correction

Sumber : Output SPSS

Hasil uji normalitas menunjukkan bahwa nilai sig. yang didapat $<$ dari 0,05 yang menunjukkan bahwa data tidak berdistribusi normal.

\section{Variabel Kualitas Informasi Terkait Order}

Tabel 13 Hasil Uji Normalitas Variabel Kualitas Informasi Terkait Order

\begin{tabular}{|l|r|r|r|r|r|r|}
\hline \multicolumn{1}{|c|}{ Tests of Normality } \\
\cline { 2 - 7 } & \multicolumn{2}{|c|}{ Kolmogorov-Smirnov } & \multicolumn{3}{|c|}{ Shapiro-Wilk } \\
\cline { 2 - 7 } & Statistic & df & Sig. & Statistic & \multicolumn{1}{c|}{ df } & Sig. \\
\hline $\begin{array}{l}\text { Kualitas } \\
\text { Informasi terkait } \\
\text { Order (Sebelum } \\
\text { pandemi) }\end{array}$ & .306 & 115 & .000 & .815 & 115 & .000 \\
$\begin{array}{l}\text { Kualitas } \\
\text { Informasi terkait } \\
\text { Order (Saat } \\
\text { pandemi) }\end{array}$ & .311 & 115 & .000 & .833 & 115 & .000 \\
\hline
\end{tabular}

a. Lilliefors Significance Correction

Sumber : Output SPSS

Hasil uji normalitas menunjukkan bahwa nilai sig. yang didapat $<$ dari 0,05 yang menunjukkan bahwa data tidak berdistribusi normal.

m. Variabel Penggunaan Teknologi Informasi Oleh Customer Service

Tabel 14 Hasil Uji Normalitas Variabel Kualitas Informasi Terkait Order

Tests of Normality

\begin{tabular}{|c|c|c|c|c|c|}
\hline \multicolumn{2}{|c|}{ Kolmogorov-Smirnov } & \multicolumn{3}{|c|}{ Shapiro-Wilk } \\
\hline Statistic & df & Sig. & Statistic & df & Sig. \\
\hline
\end{tabular}




\begin{tabular}{|l|r|r|r|r|r|r|}
\hline $\left.\begin{array}{l}\text { Penggunaan } \\
\text { Teknologi } \\
\text { informasi oleh } \\
\text { Customer } \\
\text { service } \\
\text { (Sebelum } \\
\text { pandemi) } \\
\begin{array}{l}\text { Penggunaan } \\
\text { Teknologi } \\
\text { informasi oleh } \\
\text { Customer } \\
\text { service (Saat } \\
\text { pandemi) }\end{array}\end{array}\right) .304$ & 115 & .000 & .830 & 115 & .000 \\
\hline
\end{tabular}

a. Lilliefors Significance Correction

Sumber : Output SPSS

Hasil uji normalitas menunjukkan bahwa nilai sig. yang didapat $<$ dari 0,05 yang menunjukkan bahwa data tidak berdistribusi normal.

Hasil pengujian distribusi normal menunjukkan bahwa seluruh data dinyatakan tidak normal dikarenakan nilai koefisien sig $<0.05$. Hal ini menunjukkan untuk melakukan analisis varian selanjutnya harus menggunakan uji Wilcoxon.

\section{Uji Wilcoxon}

Jika asumsi data berdistribusi normal tidak terpenuhi, untuk melakukan uji varian digunakan uji non parametrik yang digunakan oleh Frank Wilcoxon. Pada tahun 1945, Frank Wilcoxon mengembangkan tes nonparametrik, berdasarkan perbedaan dalam sampel dependen, di mana asumsi normalitas tidak diperlukan. Tes ini disebut uji peringkat bertanda Wilcoxon.[6]

Uji Wilcoxon dilakukan untuk setiap variabel Logistic Service Quality yang ditanyakan. Dasar pengujian disini adalah pengujian hipotesis dimana :

H0 : Tidak Ada Perbedaan Nilai Persepsi LSQ Sebelum dan Saat Pandemi

\section{H1 : Ada Perbedaan Nilai Persepsi LSQ Sebelum dan Saat Pandemi}

Jika nilai sig $<$ dari 0,05 maka dapat disimpulkan bahwa H1 diterima atau ada perbedaan nilai persepsi LSQ sebelum dan saat pandemi.

Secara lengkapnya 13 hipotesis yang diuji adalah sebagai berikut :

Tabel 15 Hipotesis Uji Wilcoxon Untuk Seluruh Variabel

\begin{tabular}{|l|l|l|l|}
\hline No & Variabel & H0 & H1 \\
\hline 1 & Sikap dan perilaku staff & Tidak Ada & Ada Perbedaan \\
& Jasa Kurir & $\begin{array}{l}\text { Perbedaan } \\
\text { Nilai Sikap }\end{array}$ & $\begin{array}{l}\text { Nilai Sikap } \\
\text { dan perilaku } \\
\text { dan perilaku } \\
\text { staff Jasa Jasa Kurir }\end{array}$ \\
\hline
\end{tabular}

\begin{tabular}{|c|c|c|c|}
\hline No & Variabel & HO & H1 \\
\hline & & $\begin{array}{l}\text { Kurir } \\
\text { Sebelum dan } \\
\text { Saat Pandemi }\end{array}$ & $\begin{array}{l}\text { Sebelum dan } \\
\text { Saat Pandemi }\end{array}$ \\
\hline 2 & $\begin{array}{l}\text { Respon terhadap } \\
\text { kebutuhan pelanggan }\end{array}$ & $\begin{array}{l}\text { Tidak Ada } \\
\text { Perbedaan } \\
\text { Nilai Respon } \\
\text { terhadap } \\
\text { kebutuhan } \\
\text { pelanggan } \\
\text { Sebelum dan } \\
\text { Saat Pandemi }\end{array}$ & $\begin{array}{l}\text { Ada Perbedaan } \\
\text { Nilai Respon } \\
\text { terhadap } \\
\text { kebutuhan } \\
\text { pelanggan } \\
\text { Sebelum dan } \\
\text { Saat Pandemi }\end{array}$ \\
\hline 3 & $\begin{array}{lll}\text { Kompetensi Staff Jasa } \\
\text { Kurir }\end{array}$ & $\begin{array}{l}\text { Tidak Ada } \\
\text { Perbedaan } \\
\text { Nilai } \\
\text { Kompetensi } \\
\text { Staff Jasa } \\
\text { Kurir } \\
\text { Sebelum dan } \\
\text { Saat Pandemi }\end{array}$ & $\begin{array}{l}\text { Ada Perbedaan } \\
\text { Nilai } \\
\text { Kompetensi } \\
\text { Staff Jasa } \\
\text { Kurir Sebelum } \\
\text { dan Saat } \\
\text { Pandemi }\end{array}$ \\
\hline 4 & $\begin{array}{l}\text { Penanganan masukan dari } \\
\text { pelanggan }\end{array}$ & $\begin{array}{l}\text { Tidak Ada } \\
\text { Perbedaan } \\
\text { Nilai } \\
\text { Penanganan } \\
\text { masukan dari } \\
\text { pelanggan } \\
\text { Sebelum dan } \\
\text { Saat Pandemi }\end{array}$ & $\begin{array}{l}\text { Ada Perbedaan } \\
\text { Nilai } \\
\text { Penanganan } \\
\text { masukan dari } \\
\text { pelanggan } \\
\text { Sebelum dan } \\
\text { Saat Pandemi }\end{array}$ \\
\hline 5 & Kesesuaian Order & $\begin{array}{l}\text { Tidak Ada } \\
\text { Perbedaan } \\
\text { Nilai } \\
\text { Kesesuaian } \\
\text { Order } \\
\text { Sebelum dan } \\
\text { Saat Pandemi }\end{array}$ & $\begin{array}{l}\text { Ada Perbedaan } \\
\text { Nilai } \\
\text { Kesesuaian } \\
\text { Order } \\
\text { Sebelum dan } \\
\text { Saat Pandemi }\end{array}$ \\
\hline 6 & Penanganan Order & $\begin{array}{l}\text { Tidak Ada } \\
\text { Perbedaan } \\
\text { Nilai } \\
\text { Penanganan } \\
\text { Order } \\
\text { Sebelum dan } \\
\text { Saat Pandemi }\end{array}$ & $\begin{array}{l}\text { Ada Perbedaan } \\
\text { Nilai } \\
\text { Penanganan } \\
\text { Order } \\
\text { Sebelum dan } \\
\text { Saat Pandemi }\end{array}$ \\
\hline 7 & Kondisi Order & $\begin{array}{l}\text { Tidak Ada } \\
\text { Perbedaan } \\
\text { Nilai Kondisi } \\
\text { Order } \\
\text { Sebelum dan } \\
\text { Saat Pandemi }\end{array}$ & $\begin{array}{l}\text { Ada Perbedaan } \\
\text { Nilai Kondisi } \\
\text { Order } \\
\text { Sebelum dan } \\
\text { Saat Pandemi }\end{array}$ \\
\hline 8 & $\begin{array}{lr}\text { Keselamatan } & \text { dan } \\
\text { Keamanan } & \text { dalam } \\
\text { Pengiriman } & \end{array}$ & $\begin{array}{l}\text { Tidak Ada } \\
\text { Perbedaan } \\
\text { Nilai } \\
\text { Keselamatan } \\
\text { dan } \\
\text { Keamanan } \\
\text { dalam } \\
\text { Pengiriman } \\
\text { Sebelum dan } \\
\text { Saat Pandemi }\end{array}$ & $\begin{array}{l}\text { Ada Perbedaan } \\
\text { Nilai } \\
\text { Keselamatan } \\
\text { dan Keamanan } \\
\text { dalam } \\
\text { Pengiriman } \\
\text { Sebelum dan } \\
\text { Saat Pandemi }\end{array}$ \\
\hline 9 & $\begin{array}{ll}\text { Kesesuaian } & \text { waktu } \\
\text { penanganan order }\end{array}$ & $\begin{array}{l}\text { Tidak Ada } \\
\text { Perbedaan } \\
\text { Nilai } \\
\end{array}$ & $\begin{array}{l}\text { Ada Perbedaan } \\
\text { Nilai } \\
\text { Kesesuaian } \\
\end{array}$ \\
\hline
\end{tabular}




\begin{tabular}{|l|l|l|l|}
\hline No & Variabel & H0 & H1 \\
\hline \multirow{1}{*}{10} & $\begin{array}{l}\text { Kesesuaian } \\
\text { waktu } \\
\text { penanganan } \\
\text { order } \\
\text { Sebelum dan } \\
\text { Seat Pandemi }\end{array}$ & $\begin{array}{l}\text { waktu } \\
\text { penanganan } \\
\text { order Sebelum } \\
\text { dan Saat } \\
\text { Pandemi }\end{array}$ \\
\hline transportasi & $\begin{array}{l}\text { Tidak Ada } \\
\text { Perbedaan } \\
\text { Nilai } \\
\text { Kesesuaian } \\
\text { waktu } \\
\text { transportasi } \\
\text { Sebelum dan } \\
\text { Saat Pandemi }\end{array}$ & $\begin{array}{l}\text { Ada Perbedaan } \\
\text { Nilai } \\
\text { Kesesuaian } \\
\text { waktu } \\
\text { transportasi } \\
\text { Sebelum dan } \\
\text { Saat Pandemi }\end{array}$ \\
\hline Kesesuaian waktu back \\
\end{tabular}

Sumber : Pengolahan Data

Ringkasan dan kesimpulan dari uji Wilcoxon dapat dilihat dari tabel 16 berikut.

Tabel 16 Ringkasan Hasil Uji Wilcoxon Untuk Seluruh Variabel

\begin{tabular}{|l|l|l|}
\hline Variabel dan & Nilai Sig & Kesimpulan \\
\hline $\begin{array}{l}\text { Sikap } \\
\text { perilaku staff Jasa } \\
\text { Kurir }\end{array}$ & 0,921 & Terima H0 \\
\hline $\begin{array}{l}\text { Respon terhadap } \\
\text { kebutuhan } \\
\text { pelanggan }\end{array}$ & .787 & Terima H0 \\
\hline $\begin{array}{l}\text { Kompetensi Staff } \\
\text { Jasa Kurir }\end{array}$ & .873 & Terima H0 \\
\hline $\begin{array}{l}\text { Penanganan dari } \\
\text { masukan dan } \\
\text { pelanggan }\end{array}$ & .818 & Terima H0 \\
\hline Kesesuaian Order & .134 & Terima H0 \\
\hline
\end{tabular}

\begin{tabular}{|c|c|c|}
\hline Variabel & Nilai Sig & Kesimpulan \\
\hline $\begin{array}{l}\text { Penanganan } \\
\text { Order }\end{array}$ & .041 & Tolak H0 \\
\hline Kondisi Order & .974 & Terima H0 \\
\hline $\begin{array}{l}\text { Keselamatan dan } \\
\text { Keamanan dalam } \\
\text { Pengiriman }\end{array}$ & .048 & Tolak H0 \\
\hline $\begin{array}{l}\text { Kesesuaian waktu } \\
\text { penanganan order }\end{array}$ & .001 & Tolak H0 \\
\hline $\begin{array}{l}\text { Kesesuaian waktu } \\
\text { transportasi }\end{array}$ & .001 & Tolak H0 \\
\hline $\begin{array}{l}\text { Kesesuaian waktu } \\
\text { back order }\end{array}$ & .217 & Terima H0 \\
\hline $\begin{array}{l}\text { Kualitas } \\
\text { Informasi terkait } \\
\text { Order }\end{array}$ & .130 & Terima H0 \\
\hline $\begin{array}{l}\text { Penggunaan } \\
\text { Teknologi } \\
\text { informasi oleh } \\
\text { Customer service }\end{array}$ & .081 & Terima H0 \\
\hline
\end{tabular}

Dari 13 hipotesis yang diuji terdapat empat hipotesis yang menolak H0 dan sisanya adalah menerima H0. Artinya bahwa terdapat empat variabel LSQ yang mendapatkan penilaian yang berbeda dari pelanggan sebelum dan pada saat pandemi, sedangkan sisanya tidak ada perbedaan penilaian yang berbeda dari pelanggan sebelum dan pada saat pandemi.

Uji Wilcoxon telah dilakukan untuk setiap variabel LSQ yang ditanyakan. Dasar pengujian disini adalah pengujian hipotesis dimana :

H0 : Tidak Ada Perbedaan Nilai Persepsi LSQ Sebelum dan Saat Pandemi

H1 : Ada Perbedaan Nilai Persepsi LSQ Sebelum dan Saat Pandemi

Jika nilai sig $<$ dari 0,05 maka dapat disimpulkan bahwa H1 diterima atau ada perbedaan nilai persepsi LSQ sebelum dan saat pandemi.

Dari 13 hipotesis yang diujikan terdapat 4 hipotesis yang hasilnya menolak $\mathrm{H} 0$, atau kesimpulan yang diambil dari pengujian Wilcoxon adalah 4 variabel LSQ diberi penilaian yang berbeda secara signifikan antara sebelum pandemi dan saat pandemi, yaitu Penanganan Order, Keselamatan dan Keamanan dalam Pengiriman, Kesesuaian waktu penanganan order, dan Kesesuaian waktu transportasi. 


\section{KESIMPULAN}

Dapat diambil kesimpulan bahwa variabel-variabel yang mendapat penilaian berbeda secara signifikan sebelum dan saat pandemi adalah variabel-variabel yang terkait dengan proses penanganan order (penanganan order, keselamatan dan keamanan dalam pengiriman, kesesuaian waktu penanganan order, dan kesesuaian waktu transportasi). Pelaksanaan protokol kesehatan dan aktivitas lockdown saat pandemi diduga berdampak pada terjadinya perbedaan penilaian pada saat sebelum dan terjadinya pandemi.

Para pengusaha jasa kurir logistik perlu memperhatikan hal ini, yaitu lebih memperhatikan prosedur penanganan order pada saat pandemi dibandingkan dengan sebelum pandemi. Dampak pandemik menimbulkan keharusan perusahaan jasa kurir untuk lebih memperhatikan prosedur penanganan order. Prosedur penanganan order pada saat pandemik harus dapat memberikan rasa lebih aman (terhindar dari rusak fisik, atau tercemar virus) bagi konsumen, dan waktu penanganan order (penangangan order dan transportasi) yang lebih sesuai dengan yang dijanjikan.

\section{REFERENSI}

Jurnal:

[1] Cai Q, Yang M, Liu D, et al. Experimental Treatment with Favipiravir for COVID-19: An Open-Label Control Study. Engineering. 2020;6(10):1192-1198. doi:10.1016/j.eng.2020.03.007

[2] Restuputri DP, Indriani TR, Masudin I. The effect of logistic service quality on customer satisfaction and loyalty using kansei engineering during the COVID-19 pandemic. Cogent Bus Manag. 2021;8(1):0-35. doi:10.1080/23311975.2021.1906492

[3] Biswas TK, Das MC. Selection of the barriers of supply chain management in Indian manufacturing sectors due to Covid-19 impacts. Oper Res Eng Sci Theory Appl. 2020;3(3):1-12. doi:10.31181/oresta2030301b

[4] Thai V V. Logistics service quality: Conceptual model and empirical evidence. Int $J$ Logist Res Appl. 2013;16(2):114-131. doi:10.1080/13675567.2013.804907

[5] Tedjakusuma AP, Delananda A, Andajani E. Pengaruh Logistics Service Quality Terhadap Customer Satisfaction dan Customer Loyalty Pada Industri Ritel di Indonesia. KELUWIH J Sos dan Hum. 2020;1(1):21-29. doi:10.24123/soshum.v1i1.2669

\section{Texbooks:}

[6] Douglas A L, William G M, Samuel A W. Statistical Techniques in Business and Economics (Seventeenth Edition). Vol 45.; 2017. doi:10.1057/jors.1994.177 